\title{
On the Role of Faith in Sustainability Management: A Conceptual Model and Research Agenda
}

\author{
Fabien Martinez ${ }^{1}$
}

Received: 7 June 2016/Accepted: 7 April 2017/Published online: 24 April 2017

(C) The Author(s) 2017. This article is an open access publication

\begin{abstract}
The objective of this article is to develop a faith development perspective on corporate sustainability. A firm's management of sustainability is arguably determined by the way decision-makers relate to the other and the natural environment, and this relationship is fundamentally shaped by faith. This study advances theoretical understanding of the approach managers take on sustainability issues by explaining how four distinct phases of faith development-improvidence, obedience, irreverence and providence-determine a manager's disposition towards sustainability. Combining insights from intentional and relational faith development theories, the analysis reveals that a manager's faith disposition can be measured according to four interrelated process criteria: (1) connectivity as a measure of a manager's actual engagement and activities aimed at relating to sustainability; (2) inclusivity as a measure of who and what is included or excluded in a manager's moral consideration; (3) emotional affinity as a measure of a manager's sensitivity and affection towards the well-being of others and ecological welfare; and (4) reciprocity as a measure of the degree to which a manager is rewarded for responding to the needs and concerns of 'Others', mainly in the form of a positive emotional (and relational) stimulus. The conceptual model consolidates earlier scholarly works on the psychological drivers of sustainability management by illuminating our search for a process of faith development that connects with an
\end{abstract}

Fabien Martinez

f.martinez@qmul.ac.uk

1 School of Business and Management, Queen Mary, University of London, Mile End Campus, London E1 4NS, UK increasingly complex understanding of the role of business in society.

Keywords Corporate sustainability - Faith development · Intentional faith · Relational faith · Generativity · Redemption

\section{Introduction}

This article draws from psychological theories of faith development to articulate a conceptual framework that clarifies the relationship between a manager's faith and a firm's approach to sustainability. Sustainability is a domain in which corporate managers are due to deal with diverse conflicting and/or interrelated concerns that challenge their own faith. They must often meet these challenges intuitively with limited understanding of the processes which either lead them to bend personally held convictions for business purposes, or to break business routine to enact personally held convictions, such as those related to sustainability concerns. A characteristic of sustainability that makes it a legitimate source for faith is that it reflects a desired future or a better world, one in which human economic activities are made to develop in harmony with the goals of social equity and ecological integrity (Elkington 1999, 2004). Proponents of sustainable development have often emphasised the need for an increased capacity by decision-makers and management teams across all business functions and processes to demonstrate positive feelings towards (and care for) the well-being of future generations (e.g., Gladwin et al. 1995; Viederman 1994; World Commission on Environment and Development 1987). Referring to sustainability management as a matter of 'feelings' and 'caring capacity' means to conceive the 
subject in terms of a manager's psychological and moral attributes aimed at relating to the needs and concerns of 'Others' (Roslton 1994)-i.e., a domain that management scholars have engaged with (e.g., Boudens 2005; Kahn 1990; Schwarz 2000), but never to the extent of incorporating insights from faith-related disciplines.

Recent research on the psychological factors that determine a firm's strategic response to sustainability has essentially attended to the role of managerial cognition (Hahn et al. 2014, 2015). Arguments relating to this research stream consider how corporate managers subjectively interpret their environments (Nadkarni and Barr 2008), and how they act to influence the development of collective capabilities, filters, logics, maps, and structures which shape the strategy of the firm (Healey et al. 2015; Helfat and Peteraf 2015). One recurring claim is that individuals invariably attempt to adapt and align their decisional behaviours to fit into a specific social contextas in the case of the combined pursuit of business sense and sustainable performance through business case and paradoxical cognitive frames (Hahn et al. 2014). The idea of sustainability management by adaptation and alignment is essentially grounded in cognitive economic theories. Within this view, individual rationality and consistency with dominant (business) logics determine the 'legitimate' patterns of decision-making. Corporate leaders tend to espouse the tensions between sustainability issues and business imperatives (Van der Byl and Slawinski 2015), which appears to sustain 'business as usual' in lieu of supporting the pursuit of a distinctively more sustainability-oriented pathway (Wright and Nyberg 2016). That is in spite of the evidence that conventional business decision patterns, based on cognitive calculation and essentially aimed at raising profits by 'restricting the social costs arising from human imperfections ${ }^{1}$ (Ghoshal 2005, p. 77), do not cope well with the complexity of the processes found at the strategy level to address sustainability issues (Porrit 2009).

One criticism that can be levelled at much of the theoretical contributions to sustainability management from a cognitive economics perspective is their reliance on a rather parsimonious characterisation of the worlds of cognition and morality (Harris and Freeman 2008; Paquet 1998). They reflect, or perhaps stem from, a static view of the world (Roome and Louche 2016), a set of pessimistic assumptions about the role of individual morality in business and a climate of relative 'apostasy' in sustainability management that are likely to make little real difference in the decisional behaviour of organisations (Ghoshal 2005;

\footnotetext{
${ }_{1}$ A phenomenon discussed by Secchi (2007) as part of utilitarianism, in which the corporation is intended as a maximising 'black box' where problems of externalities and social costs emerge.
}

Singer 2016). Alternative theoretical resources ought to be developed in order to understand how corporate managers develop their capacity to project themselves to the future and make choices that seek to reconcile the powerful and complex social constructions that influence their thinking with the material reality of the environment (Robbins et al. 2010). Hawken (1994) explains that industry is the only institution in the modern world that is large, pervasive and powerful enough to foster the changes that are necessary for sustainability progress. It is arguably the moral responsibility of corporate managers, and hence business organisations, to provide a platform from which the industry can move towards more rewarding ways of coping with environmental and social issues (Swanson 2014). An assumption that has not received considerable scholarly support in organisation and management studies is that corporate responses to sustainability concerns at the strategy level partly depend on the potential of managers to develop their faith in sustainability (e.g., Gladwin et al. 1995; Johnston 2014; Pache and Santos 2013; Swanson 1999).

Faith as a universal human process involves individuals attempting to find meaning in their lives by placing their trust and loyalty in some attractive centre(s) of value that may be found in the workplace and represent(s) for them a reality that is sustaining, reliable and dependable (Niebuhr 1960). It often relates to a belief in something for which there is a lack of knowledge and considerable uncertainty and complexity, like sustainability itself (Judge and Douglas 2013). Appropriation of the concept of faith in this article leads to the argument that corporate managers do not thrive solely on cognition and emotionless reasoning to build their disposition, or perspective, regarding the future of their firms. Affective elements too play their part. In discussing the construct of faith, Immink argues:

Knowing and trusting are not merely rational matters, but they resonate in our affections and ambitions. Our inner drives, our emotions, and our goals play their part. Faith is able to lead people to do things. Our affections are stimulated, and our drives and ambitions are involved (2005, p. 31).

Moral philosopher and founder of capitalism Adam Smith accredited the idea that emotions matter and are likely to influence the way corporate managers relate to societal problems. He wrote:

How selfish soever man may be supposed, there are evidently some principles in his nature, which interest him in the fortune of others, and render their happiness necessary to him, though he derives nothing from it, except the pleasure of seeing it. Of this kind is pity or compassion, the emotion which we feel for 
the misery of others, when we either see it, or are made to conceive it in a very lively manner. (2002 [1759], p. par. I.1.1)

The appeal of faith as an element of human potential that embraces cognition and affection lies essentially in its capacity to provide for a more holistic (and perhaps realistic) understanding of the role of individuals in business. Faith has often been the subject of vehement criticism from academic scholars in management, corporate sustainability and ecological economics disciplines. Some critics point to the substantial influence of negative biases towards cynicism, selfishness, greed and apathy as part of the individual characteristics that influence a firm's capacity to address environmental problems such as biodiversity loss, ecosystem collapse and climate change (e.g., Gladwin 2011; Gladwin et al. 1995; Harvey 2015; Speth 2009; Viederman 1994). These characteristics are associated with a low level of faith in sustainability principles, and by extension a tendency towards reckless exploitation of nature for material gains by individuals and businesses (Tucker 2015). It is essentially this 'enduring' pattern ${ }^{2}$ that led a number of scholars to call for the emergence of a new management paradigm (e.g., Dehler and Welsh 1994; Ghoshal 2005; Gladwin et al. 1995), one in which the value of individual morality is redeemed by forming an integral part of both the practice and theorising of management (Hemingway and Maclagan 2004). Long established by psychologists and theologians (e.g., Fowler 1991, 2001; McDargh 2001), the ways in which faith shapes individuals' cognitive structures and moral judgments have not yet been explored in the analysis of corporate sustainability, despite the recognition that strong sustainability performance in business requires a 'leap of faith' for managers who need to raise their awareness of, and sensitivity to, sustainability issues beyond those encountered in their immediate work responsibilities (Haugh and Talwar 2010; Swanson 2014).

In response to this knowledge gap, this study explores the phenomenon of faith development as part of the individual factors that influence processes of change and determine the valence of management decisions and actions towards sustainability progress. The article begins by presenting an overview of the literature covering aspects of the relationship between business and faith. Scholars in the fields of workplace spirituality, corporate sustainability and corporate governance have used varied theoretical resources that focus on individual mindset, the need for

\footnotetext{
2 There is no shortage of literature counting stories of corporate leaders and managers implicated in ethical scandals, such as those of Andy Coulson from News Corporations, Al Dunlap from Sunbeam, Dennis Kozlowski from Tyco, Bernie Ebbers from Worldcom, and Richard Scrushy from Health-South (Treviño and Brown 2004).
}

consistency, the approach to conflict and leadership style as variables that are linked to a certain level of variability in the faith orientations of corporate managers. In the next part of the article, the analysis draws on the main scholarly contributions to the faith development theory to identify and define four distinct phases of faith development: improvidence, obedience, irreverence and providence. Insights from intentional and relational faith development theories are then integrated to unpack the construct of a conceptual model constituted in terms of four process criteria that shape a manager's faith orientation: connectivity, inclusivity, emotional affinity and reciprocity. Key aspects of the model that will guide future research are finally outlined.

\section{Corporate Sustainability and Faith: Identifying the Emerging Constructs}

Growing scholarly and popular interests in the domain of workplace spirituality have given momentum to the idea that the development of individual faith is an important part of both decision-making and action-taking in business-including offices, factory floors and manufacturing plants (Miller et al. 2013). Studies of the intersection of religious traditions ${ }^{3}$ with the practice of business have garnered an important part of scholarly attention in this domain (e.g., Brammer et al. 2007). The emergence of the concept of spiritual leadership (Fry 2003), and our attempts at answering the question of how spirituality relates to one's work organisation (Herman and Schaefer 2001), have generated substantial improvements in our understanding of spiritual influences on corporate managers. One reason that makes spirituality relevant to business is that it is infinitely malleable in the direction of inclusiveness. It constitutes a source of value systems, ${ }^{4}$ moral points-ofview, virtues and codes of conduct, and a useful contribution to management wisdom generally imbued with overreliance on economic calculations, control systems and exclusivist standpoints such as materialism and individualism (Meera and Bonin 2014). However, management scholars have only parsimoniously explored how spiritual attachments and religion's influence manifest in business organisations (King 2008), despite the global crisis of the past decade (economic, financial, food, energy, health, migration and security) calling into question the ideologies

\footnotetext{
3 These include the Buddhist, Christian (Roman Catholic, Eastern Orthodox, African-American Protestant, Baptist, Evangelical, Lutheran, Mennonite, and Mormon), Jewish and Muslim traditions.

${ }^{4}$ For example, the faith-based development organisations in Cairo illustrate how Islamic values influence the management of sustainability issues (Atia 2012).
} 
and belief systems underpinning extant institutional and organisational configurations.

Several commentators have referred to the influence of individual faith as part of their studies of the structural flaws that caused the financial crisis of the late $2000 \mathrm{~s}^{5}$ (e.g., Cooper 2015; Crotty 2009). The premises of an argument about how faith relates to events of the corporate world, and drives the activities of financial institutions and business in general, started to emerge. These events, and the literature that covered them, have thrown light on one particularly strong type of faith placed by business agents in the stability characteristics of free markets. The doctrine of the sanctity of the free market (or 'neo-liberal dogma') has been a dominant feature of business agents' faiths for the past 30 years, partly articulated with the key institutions of capitalism through the models of financial economics developed in Universities' accounting and finance departments ${ }^{6}$ (Cooper 2015). One fundamental pillar of the neoliberal dogma is the idea that representative individuals for households and firms are able to optimise by modelling the economy. These individuals invariably rely on the market as a superior governance function and an "invisible hand" ${ }^{7}$ that holds sacrosanct their (neo-) liberal beliefs in 'laissezfaire'. The dominance of this type of faith, which is referred to as a pattern of 'obedience' later in this article, is now increasingly considered inadequate, mainly because financial markets have proven imperfect and vulnerable to speculation, manipulation, demand fluctuation and a variety of external shocks to financial systems.

The realisation that markets are unworthy of a largely unquestioned faith has led some scholars to challenge the ideological roots of contemporary capitalism and advocate for a shift in our conception of the role of business in society, and of the role of individual managers in business (e.g., Gladwin 2011; Gladwin et al. 1995; Gond and Crane 2010). Implicit in this quest for a new 'management' paradigm is the idea that individuals ought to develop new forms of faiths that are distinctively more attuned to the promotion of sustainability principles and practices and in which economic prerogatives are 'one' element of strategising, not 'the' strategic priority. As mentioned in the introduction, sustainability confronts managers with situations in which they need to address multiple desirable but

\footnotetext{
5 Long-held faith that markets such as real estates would continue to rise provoked misplaced optimism from private investors, traders and financial institutions (Crotty 2009).

${ }^{6}$ Economic scholars from the Chicago School were particularly instrumental in reducing the idea of expectations to the domain of knowable outcomes with attached probabilities (Friedman 1953).

7 The invisible hand theory of Adam Smith entails that, driven by self-interest, individuals will use capital to address market needs, creating value for both consumers and themselves (Sullivan and Sheffrin 2003).
}

potentially conflicting economic, environmental and social outcomes at various levels of strategy formation (Hahn et al. 2014). Gladwin et al. (1995) argue that such a challenging goal for corporate sustainability demands a widening of the scope of human choices to promote inclusiveness, connectivity, equity, prudence and security. If the need for stability and consistency of individuals who are confined within the boundaries of management systems of conventional efficiency-driven and/or shareholder-oriented corporations might limit the scope of human choices to those that repeatedly generate the most instrumental outcomes for the firm (Robert Mitchell et al. 2011), a sustainability-oriented approach to management highlights the need to broaden the scope of human choices to include those that enable managers to reconcile inconsistencies in economic, natural and social systems (Van der Byl and Slawinski 2015), thus enhancing the commensurability of business with a more sustainable form of development (Valente 2012). The present study argues that the capacity to widen the spectrum of human choices in strategic decision-making is critically dependent on faith as an individual and/or collective journey of growth, development and becoming. Business leaders and top management teams are portrayed as capable of developing their faiths in ways that alter or suppress the need for consistency with unsustainable ways of doing business. They may instead cultivate a proclivity for reconciling any inconsistencies between business and sustainability aspects (Smith and Lewis 2011). The development of faith in this sense translates onto a growing potential of business managers to challenge the prevalence and appropriateness of conventional institutional logics to address sustainability issues, often rooted in outdated mental models and perspectives (Hopkins 2009).

As management thinkers and practitioners strive to reshape and reframe our conceptions of the role of business in society to respond to increasingly complex economic, social and environmental challenges, exploring the individual and collective faith development processes that are at play can be viewed as an opportune and timely endeavour. It has long been widely recognised that individuals are motivated by a much wider range of concerns than simple self-interest. Not only may non-self-interest behaviours (e.g., altruism, corporate philanthropy) be important, but so too may be other characteristics, like 'cooperativeness', 'social approval' and so forth. What remains understudied in research into business ethics and spirituality is how multiple individual faiths co-exist to form a collective faith that determines a firm's ethical commitment. Business contexts, like all social situations, may inherently contain conflicting moral considerations that influence processes of change (Smith and Tushman 2005). One argument in the present study is that leadership skills act as a catalyst for the translation of faiths into 
consensual decisions and actions, or, in business terms, sustainability-oriented strategies and operations. They might determine which moral considerations will take prevalence, or how these will be syncretised, in the event of plurality or conflicts. Manager's response to conflicts has been a recurrent theme in recent studies of tensions and paradoxes in corporate sustainability (e.g., Hahn et al. 2014, 2015; Van der Byl and Slawinski 2015), suggesting various individual and collective capacities to pursue prosustainability solutions in the face of conflict and uncertainty.

Corporate governance scholars have often discussed leadership as an attribute for individuals occupying dominant positions (e.g., at the top of hierarchies) and seeking to define and diffuse ethical principles in their organisations (e.g., Arjoon 2005; Burnes and By 2011; Tian et al. 2015). Other scholars in the same field have explored the potential of business leaders to either harness or limit the influence of a new faith emerging from lower hierarchical echelons (e.g., Minkes et al. 1999). A new wave of management studies has endeavoured to reshape our view of corporate governance models, and of leadership within these models. The (old) traditional view is that of corporations as closed systems with clearly established institutional, functional and hierarchical boundaries. ${ }^{8}$ Most contemporary corporations still operate in a closed system, according to strict routines and 'effortless' measurement mechanisms that ensure against disorder, inefficiencies and uncertainty. Within this view, individuals are organised in a set of positions and the role of corporate leaders is mainly confined to secure ongoing synchronicity, ordering and certainty in day-to-day business activities (Eisenhardt and Zbaracki 1992). The emerging view is that of corporations as open systems with greater reliance on transparency, cocreation and dialogues with stakeholders such as employees, external partners, civil society organisations, suppliers, customers and competitors (Sai Manohar and Pandit 2014; Secchi 2007). Appropriation of the concept of open and social innovation by management scholars constitutes a major step within this trend (Martinez et al. 2017). Interestingly, the creation of corporate vision and pro-sustainability value congruence across individual levels in the context of open innovation is often argued to require a leap of faith (e.g., Haugh and Talwar 2010; Mahoney et al. 1994) - translating onto the development of a distinctively more inclusive mindset that determines the right (or ethical) course of action, particularly when operating under situations of uncertainty and ambiguity (Treviño et al. 2000; Van den Steen 2005). If multiple religious faiths, and

\footnotetext{
${ }^{8}$ A view suggested by Secchi (2007) as belonging to the managerial group of theories, where problems of responsibility are approached from inside the firm.
}

potential sources of spiritual leadership, can be found at all levels of a firm's internal and external environment, little is known about how individuals holding management positions in (postmodern) organisations elevate their faith in reason to a level at which it becomes equated with sustainability progress (Parker 1992).

Overall, the notion of faith has been a recurrent, yet often inexplicit, theme within corporate sustainability debates, and concomitant theoretical developments. The discussion above throws light on several explanatory variables that represent how individual faiths appear to be manifested in the context of corporate sustainability: individual mindset (or worldview), need for consistency, response to conflict, and leadership style. Table 1 synthesises the theoretical background of each variable and raises the assumptions that justify their integration as components in a faith development perspective on corporate sustainability.

\section{Phases of Faith Development}

Fowler's (1981) theory of psycho-spiritual development has been an important starting point for various theories and subsequent studies of faith development. Although the theory has generated lively critical scholarly response from psychologists and theologians (e.g., Coyle 2011; Heywood 2008; McDargh 2001), it represented a major breakthrough in the integration of religion and psychology (Jardine and Viljoen 1992). In bringing together important features of several developmental models, namely those of Piaget (1967), Erikson (1950), Kohlberg (1981) and Selman (1976), Fowler has situated faith development squarely within the domain of human developmental processes, in the same way that Gladwin et al. (1995) have situated the management of sustainable development as a process of achieving human development. The theory supports the idea of a developmental process in 'human faith' main argument being that faith develops in stages towards a point of maximal individuation of the self and corresponding minimisation of the personal ego as the standpoint from which evaluations are made (Fowler 1991).

Fowler (1991) drew upon Piaget's (1967) theory of cognitive development and Kohlberg's (1981) stages of moral development to propose seven major stages of faith development, which he classifies from stage 0 to stage $6 .{ }^{10}$ He defined the theory as 'a developmental account of the

\footnotetext{
${ }^{9}$ The theory was originally developed on the basis of interviews with people from a wide range of ages and faith identifications (Fowler 1981).

${ }^{10}$ Since it will not be possible to discuss Fowler's stages in detail here, interested readers may consult Fowler's (1991) article for a description.
} 
Table 1 Components of a faith development perspective on corporate sustainability

\begin{tabular}{llll}
\hline Variable & Literature background & Key authors & $\begin{array}{l}\text { Core assumption in relation to faith } \\
\text { development }\end{array}$ \\
\hline $\begin{array}{c}\text { Mindset (or } \\
\text { worldview) }\end{array}$ & $\begin{array}{l}\text { Corporate sustainability scholars have } \\
\text { advocated for a paradigmatic shift in } \\
\text { management behaviour. They have } \\
\text { tended to regret the inability of the field } \\
\text { of management to move away from the } \\
\text { dominant economic paradigm that } \\
\text { continues to undermine the capacity of } \\
\text { businesses to contribute more }\end{array}$ & $\begin{array}{c}\text { Valente (2012), Gladwin et al. } \\
\text { (1995), Ghoshal (2005), Starik and }\end{array}$ & $\begin{array}{l}\text { A manager's faith may develop in ways } \\
\text { that spark interest in broader moral } \\
\text { principles than those related to economic } \\
\text { aspects. Sustaincentrism offers a set of } \\
\text { principles that are well suited to define } \\
\text { the attributes of a manager whose faith } \\
\text { translates into a proclivity to foster } \\
\text { sustainability progress }\end{array}$
\end{tabular}

substantively to the sustainable

development of our societies. In the face

of threats of serious or irreversible

damage, business leaders and scholars

ought to subscribe to a distinctively more

responsible set of values, beliefs and

expectations in relation to

development-one that transcends

technocentrism and ecocentrism into

sustaincentrism $^{\text {a }}$

Need for Institutional theories of organisations have

consistency influenced a substantial part of corporate sustainability research in the last three decades. This stream of research has essentially focused on the role of social influence and pressures for social conformity in shaping organisations' actions. The positioning theory applied in the areas of organisational change and workplace agency specifies that individuals choose institutional sets of rules as most consistent with their roles at a moment in time

Response to Corporate sustainability scholars have conflict essentially drawn from cognitive economics to understand how managers address multiple desirable but potentially conflicting economic, environmental and social outcomes inherent to sustainability. These studies tend to be based on a narrow conception of the cognitive potential of individuals that promote status quo and rely on a rather pessimistic view of the role of individuals, and their ability to transcend themselves and others, in business.

Leadership style
Institutional theory: DiMaggio and Powell (1983)

Positioning theory: Davies and Harré (1990)

Organisational change: Zelle (2009)

Workplace agency: Redman (2013)

Van der Byl and Slawinski (2015), Hahn et al. (2010)

Hahn et al. (2014, 2015, 2016)
'Consistency' of actions and decisions with the social context are partly shaped by individuals' faiths and conceptions of truth. A manager's faith may develop in ways that widen the scope of his or her decisions and actions beyond maintenance of consistencies with existing norms and values (e.g., institutional context, 'business as usual') to focus attention on emerging inconsistencies in economic, natural and social systems

A manager's faith may develop in ways that generate a positive developmental strategy in the face of conflicting moral considerations and expectations, fostered by tolerance, reconciliation and consensual decisions and actions
Authentic leadership: Luthans and Avolio (2003), George (2003), Bass and Steidlmeier (1999), Avolio and Gardner (2005)

Transformational leadership:

Kuhnert and Lewis (1987),

Waldman et al. (2006)

Positive organisational behaviour: Luthans and Youssef (2007)
A manager's faith may develop in ways that generate high levels of motivation and purpose, with a conception of business leaders/managers as increasingly prone to support the sustainability cause and set examples to be emulated by followers and actions to address sustainability concerns. The notions of transformational leadership and positive organisational behaviours entail that leaders and followers ought to raise one another to high levels of motivation and purpose

\footnotetext{
${ }^{a}$ For details about the key assumptions of technocentrism, ecocentrism and sustaincentrism, see Gladwin et al. (1995)
} 
growing capacities, in humans, for sharing and responding imaginatively to symbols, narratives, and rituals that invite participation in the sacred, and that touch the deepest dimensions of our relatedness to the Holy' (Fowler 2004, p. 413). Locus of authority, sense of belongingness and identity, referent narratives, symbols, rituals and worldviews are the main characteristics of the reflexive individual that drives his or her maturation towards the highest stages of faith development (Fowler 2004). Recent advances in the theorising of corporate commitment to sustainable development made interesting connections to similar individual characteristics whilst exploring the institutional drivers (Whitehead 2014), moral agency challenges (Singer 2016), narratives (Philippe and Bansal 2013) and cognitive processes (Hahn et al. 2014) that are at play in organisations that embrace a sustainability agenda.

Peck (1987) drew upon Fowler (1981) and Kegan (1982) to develop a theory of human spiritual growth that is not tied to age, maturation and epigenetics (unlike Fowler's model) but related to socio-cultural aspects such as the development of religious faith and meaning making. The theory consists of a simplified four stages taxonomy including the chaotic/antisocial stage, the formal/institutional stage, the sceptic/individual stage and the mystical/communal stage. ${ }^{11}$ Arguably, in an analysis of how corporate managers develop faith, the most likely stages of faith development which determine a firm's approach to sustainable development and ethics are the latest three. The chaotic/antisocial type defines manipulative and self-serving individuals characterised by undeveloped spirituality (Peck 1987). The terms 'chaotic' and 'antisocial' may be seen as inadequate to the description of a management position in the corporate place. Corporate managers tend to be represented as individuals who are emotionally connected to business goals and to others in the service of these goals (Kahn 1990; Rich et al. 2010). Equipped with a certain level of cognitive vigilance, focus, attention and awareness, they feel responsible and in relative control. These individual characteristics act to prevent the occurrence of (or at most render unlikely) chaotic and antisocial stages of faith. This is not to argue that corporate managers are immune from 'transitional' phases and a certain level of variability in the development of their faith, including the possibility of going through a phase in which faith is relatively undeveloped and impulsive behaviours are made possible (Kegan 1982).

Erikson's (1950) lifespan theory supports the idea that corporate managers go through a variable developmental process. One argument is that individuals reaching career pinnacles, and possibly holding management or leadership

\footnotetext{
${ }_{11}$ For a complete description of these stages of spiritual growth, see Peck (1987).
}

ranks in corporations, undergo conflicting tendencies towards 'generativity' and 'stagnation'. Generativity involves productive and creative activity motivated by a farsighted ethic of intergenerational care and attention to others; stagnation on the other hand equates to narcissistic self-absorption (Hoare 2001). Erikson thus proposes a universally experienced life stage conflict where a motivated ethic (i.e., high stages of faith development) and a state of ethical decay (i.e., low stages of faith development) compete to be dominant influences on behaviour (Marshall et al. 2013). In the same vein, corporate sustainability research (particularly in relation to management and leadership) has established the existence of conflicting motivations and inconstant aptitudes from individuals to orient themselves to a view of the corporate world as seen through the lenses of sustainability (e.g., Aguilera et al. 2007; Kuhnert and Lewis 1987; Valente 2012; Van der Byl and Slawinski 2015; Zadek 2004). These aptitudes are likely to be better understood through application and amplification of the faith development theory. The taxonomy developed by Peck (1987) is a useful point of reference because it accommodates Erikson's generativity versus stagnation continuum, and its main tenets are applicable to the study of individuals holding management ranks in corporations. The term 'phase' is used in this article to define the major aspects in which the varying modes of faith development are manifested in management contexts, without advocating for an 'epigenetic' sequence of stages (Fowler 1991), rather by exploring the idea of a constructive developmental process based on intention and relational capacity, one that accounts for the possibility of variability in a manager's development of his or her faith throughout life events and experiences.

Using a terminology that bears a distinctive connotation of faith, four main phases are proposed in this article: (1) improvidence, (2) obedience, (3) irreverence and (4) providence. The phase of improvidence is a moderate variant of the chaotic and antisocial stage of faith development suggested by Peck (1987). Here, faith is unsettled and dependent on an egocentric mode of being, underpinned by little concern for rules or consistency. The phase of obedience is essentially derived from the formal and institutional stage of faith development proposed by Peck (1987). Here, faith is affiliative and dependent on a manager's commitment to the modes of thought that prevail in his or her organisational context, underpinned by a tendency to seek refuge in reliance on external sources of authority. The phase of irreverence is the relative equivalent to the sceptical and individual stage of faith development proposed by Peck (1987). Here, faith is inquisitive and dependent on a manager's commitment to search for the 'truth', underpinned by his or her tendency to doubt and his or her concern about moral integrity. The fourth and 
Table 2 Characteristics of the improvident, obedient, irreverent and provident phases of faith development

\begin{tabular}{|c|c|c|c|c|}
\hline $\begin{array}{l}\text { Phase of } \\
\text { faith } \\
\text { development }\end{array}$ & Worldview/mindset & Approach to conflict & Need for consistency & Leadership style \\
\hline Improvidence & $\begin{array}{l}\text { Egocentrism } \\
\text { Tendency to be self-absorbed } \\
\text { Focus on achieving his or her own } \\
\text { desires, often at the expense of others, } \\
\text { and possibly in the quest for the } \\
\text { highest pecuniary benefits } \\
\text { Proposition } 1 \\
\text { Corporate managers who exhibit the ch } \\
\text { and not offer a predictable, reliable a } \\
\text { sustainability or not }\end{array}$ & $\begin{array}{l}\text { Bend rules } \\
\text { Use 'dirty tricks' such as } \\
\text { manipulating, lying, cheating, } \\
\text { fraud and lawlessness (e.g., } \\
\text { VW emissions scandal, Ali } \\
\text { Dunlap from Sunbeam) }\end{array}$ & $\begin{array}{l}\text { Practically inexistent } \\
\text { No locus of authority } \\
\text { Weak attachment structure } \\
\text { No worthy principles such as truth } \\
\text { or love }\end{array}$ & $\begin{array}{l}\text { Arbitrary, random } \\
\text { Weak capacity of } \\
\text { foresight } \\
\text { High degree of } \\
\text { versatility }\end{array}$ \\
\hline Obedience & $\begin{array}{l}\text { Ethnocentrism } \\
\text { Commitment to the modes of } \\
\text { governance that prevail in their firms } \\
\text { Alignment with business prerogatives } \\
\text { and institutional logics } \\
\text { The firm is conceived of as an insular } \\
\text { social entity whose interests are }\end{array}$ & $\begin{array}{l}\text { Ignore } \\
\text { Select the most 'faithful' course } \\
\text { of action (e.g., business case } \\
\text { for sustainability) } \\
\text { Follow the 'letter of the law' }\end{array}$ & $\begin{array}{l}\text { Strong } \\
\text { Proclivity towards preserving } \\
\text { attachment contingencies } \\
\text { Reliance on an external source of } \\
\text { authority to provide stability and } \\
\text { security }\end{array}$ & $\begin{array}{l}\text { Conservative, } \\
\text { pragmatic } \\
\text { Authority is located } \\
\text { outside } \\
\text { themselves, hence } \\
\text { they may not feel } \\
\text { accountable }\end{array}$ \\
\hline
\end{tabular}

\section{Proposition 2}

Corporate managers who exhibit the characteristics of obedient individuals will strive to operate in a stable (and possibly rigid) system in which tangible economic aspects prevail over, or at best align with, ambiguous sustainability concerns in decision-making. Therefore, they will satisfy their need for clarity, control and consistency in their management roles while reducing the risk of breaking their bounds by altering their faith in traditional institutional logics

Irreverence

Worldcentrism, capable of ecocentrism

Quest for the truth, self-actualisation

Belief that constituents of the outside world are at least as 'independent' and capable of integrity as they are, if only they would do the work involved in determining their own values
Rely on intuition and instinct

Reject the moral considerations that they cannot see as being true
Weak

Emphasis on moral integrity and self-efficacy

Tendency to ignore external ideas and viewpoints, without fearing inconsistencies with the outside world
Individualised, disruptive (dogmatic or iconoclast),

The main goal is to preserve their moral integrity and self-efficacy

\section{Proposition 3}

Corporate managers who exhibit the characteristics of irreverent individuals will dismiss traditional business logics and approach sustainability as a means to satisfying their 'iconoclast' quest for a rupture with existing rules and norms, which underpins a risk of being isolated and rejected by their institutions. Therefore, they will commit to address sustainability issues only if they consider them morally legitimate and worthy of their investments, in line with their strong need for moral integrity and their penchant for dogmatism, possibly associated with a risk of rejection from others

Providence

Sustaincentrism (including aspects of Contemplate universalism and cosmocentrism)

Conception of business as a means to serving communities

Driven to abide by the rules of communion

Able to refer to higher spiritual sources

\section{Reconcile}

Include all moral considerations in his or her concern

Share responsibility

Follow the 'spirit of the law'

\section{Strong}

A desire for connectedness not only with their colleagues and their own institutions but with wider society

Constant contemplation of solutions for stronger unity of everyone (all social actors and institutions) and everything (e.g., animals, environment)
Transformational, contemplative, collaborative, inclusive

\section{Proposition 4}

Corporate managers who exhibit the features of provident individuals will be perceived as 'sustainability champions' who preach for a conception of business as a means to serving communities and of economic aspects in a more general sense as a narrow segment of human life 
final phase, namely providence, is essentially drawn from the mystic and communal stage of faith development proposed by Peck (1987). Here, faith is authentic and dependent on a manager's interest in serving communal needs and interests, underpinned by a strong sense of generativity. Table 2 summarises the main characteristics of each phase, in relation to the components presented in Table 1. The four phases represent distinctly diverse faith orientations and dispositions by corporate managers to enact sustainability principles, each one more likely to enhance 'responsible' management than previous ones. They may not be exhaustive of the phases of faith development that can be mapped, but they are distinct enough to cover a great variety of faith development phenomena documented in the literature and likely to emerge from the study of faith development in sustainability management. Table 2 offers propositions on how the four phases influence managerial response to sustainability issues.

\section{Faith Orientations and Intentions}

Given such faith orientations and sustainability responses, the question remains as to how managers may move across phases. The theoretical discussion converges on the argument of, e.g., Coyle (2011) and Heywood (2008) that the faith development theory formulated by Fowler is limitedly (and perhaps erroneously) construed as a sequence of stages that are invariable, hierarchical and age dependent. It supports the alternative (post-modernist) idea of a constructive developmental model (Kuhnert and Lewis 1987) — one that notably influenced aspects of reference group theory (e.g., Reichers 1985) and interactionist models of decision-making in organisations (e.g., Treviño 1986). The key assumption is that individuals experience nonlinear processes of faith development. The future course of emergent change is therefore more difficult to predict than if it were evaluated from a strict stage perspective. The approach is argued to offer a more realistic account of the dynamic processes of faith development that are experienced by individuals in sustainability management contexts.

Within this view, it is the individual's transactions with specific social contexts and reference groups that shape faith orientation and influence faith development. These transactions may subjectively constitute a negative and confronting experience for improvident managers who will tend to fight and sweep away the structures provided by the firm, and for obedient managers who will feel obliged and subordinated to the norms and rules that prevail in the firm and that are not necessarily in phase with sustainability principles. These types of transactions underpin a conception of sustainability as a 'faith threat' (Coyle 2011). In other words, sustainability represents a counterforce to the proclivity of individuals in the improvident and obedient phases to be self-absorbed (stagnation) and to favour alignment with conventional (unsustainable) business logics. Individual transactions with the social context and reference groups may instead turn into a positive and enriching experience for irreverent managers who will seek to distinguish themselves by exploring alternative routes to the 'truth' and for provident managers who will seek unity in the social context. This underpins a conception of sustainability as a 'faith opportunity', one that enables individuals to enact their own moral agency and their generative virtue of care (Erikson 1974) to weed out 'unsustainable' business routines. The challenge of corporate sustainability from a faith development perspective is thus understood to generate a continuum from a conception of sustainability as a faith threat, fostering defensive postures and pessimism (a compelled unsustainable walk on human life?), to a conception of sustainability as a faith opportunity that opens perspectives for a more optimistic view of the role of individuals in business and the development of human potential to foster sustainability progress. The question of how managers might develop faiths in ways that foster a collective transition from pessimism to optimism remains to be explored.

One pattern of faith development that Hart (2007) uncovered in a study of J. Robert Oppenheimer's psychological history is the extent to which an individual's life and thought are permeated with themes and ideas of an ethical nature that shapes his or her character and informs his or her view of the world. For example, founder and former CEO of Interface Ray Anderson was fundamentally influenced by the generativity of his father, his coach and his professors (Douglas Creed et al. 2014), as well as ideas from Hawken's (1994) 'Ecology of Commerce', to construct his developmental path to become a generative business leader, and to establish his legacy as a leading international champion of corporate environmental stewardship. That relates to an argument in business ethics research that moral judgment processes, such as faith development, depend on the development of moral awareness, and a proclivity towards recognising, and being sensitive, to ethical and sustainability issues (Treviño and Brown 2004). According to the intentional faith development theory inspired by the theology of Lonergan (1970, 1972), it is the responsible exercise of freedom and the search for an integrating centre of value and meaning that determine a manager's moral awareness, issue recognition and ethical sensitivity (Clore and Fitzgerald 2002). Individuals are free to deliberate and evaluate in order to act according to the judgements of value they have established (Clore and Fitzgerald 2002).

Exploring how managers enact their responsible exercise of freedom may enable us to understand how faith 
develops to a level at which it might catalyse a positive (responsible) attitude of management towards sustainability. Two variables are identified as core to intentional faith development: an individual's targeted mode of commitment and his or her focus (or object(s) of concern) (e.g., Atchley 1997; Wink and Dillon 2002; Wuthnow 1998). The variety of managerial faith-based responses to sustainability issues that are contemplated in this article is illustrated in the form of a two-dimensional matrix in Fig. 1. The characteristics of the four phases of faith development proposed in this article (cf. Table 2) are used to specify what the object(s) of concern and targeted commitment are likely to be in each phase.

According to Bass and Steidlmeier (1999), a moral agent is evaluated as praiseworthy or blameworthy partly in the light of his or her probity of intentions and the end sought. If in the quest for optimised corporate sustainability performance the provident phase of faith development is argued to portray the 'praise-worthiest' managers, equating sustainability performance with a particular mode of commitment, or a single distinctive object of concern, or even a selection of positive psychological states, might fail to capture what is distinctively complex and dynamic about an individual's commitment to faith in the context of sustainability management. It may induce the risk of isolating certain individuals (who may go through a phase of heightened vulnerability) as morally culpable without examining and questioning the faith development context-i.e., the unique combination of elements from various phases of faith development that drives the goals, strategies and environment for decision-making in which the corporation operates (Hoffman 1986).

This acts to re-emphasise the (post-modernist) aim of this study to stray from a strict stage perspective and promote instead a distinctively non-discriminating and socially contingent process of development. The main idea is that the elements of each phase exist in some form within every individual before the time when it becomes 'phasespecific', that is when a modification of their actual power to influence managerial decision and behaviour is precipitated by a change in individuals' object(s) of concern and/ or mode of commitment. The socially contingent factors that underpin change of intentional activities aimed at relating to 'Others' are articulated in scholarly contributions to relational faith development theory-particularly those that connect with elements of generativity models.

\section{Processes of Faith Development}

Erikson's $(1964,1974)$ discussion of psychosocial stage resolution suggests that individuals achieve an integration between polar outcomes, or in the case of the matrix presented in Fig. 1 between elements of the four faith orientations, and arrive at their own unique synthesis of phasespecific elements, rather than a stark alignment with either. In this way, the experience and expression of pro-sustainability engagement (or of generativity, with its emphasis on caring for others) does not necessarily eliminate the experience or expression of selfish utility maximising behaviours and instrumental business case (or of stagnation, with its emphasis on authoritism and rejectivity) (Bradley 1997). Faith development is therefore construed as a continuous reworking of one's faith, characterised by a constant transformation of an individual's mode of commitment and object(s) of concern.

Generativity scholars have delineated the process criteria that are likely to be reflected in the attitude of individuals who are called upon to be responsible for others (e.g., Bradley 1997; Kotre 1984; McAdams 2013; McAdams and Guo 2015; Snarey 1993). McAdams (2013, 1992, 1993) developed a complex model of generativity consisting of seven interrelated variables: inner desire, cultural demand, concern for the next generation, a 'belief in the species', a commitment to specific goals, generative actions and a personal narrative (what McAdams referred to as a 'generativity script') that fits the person's life story into a larger legacy. This model was

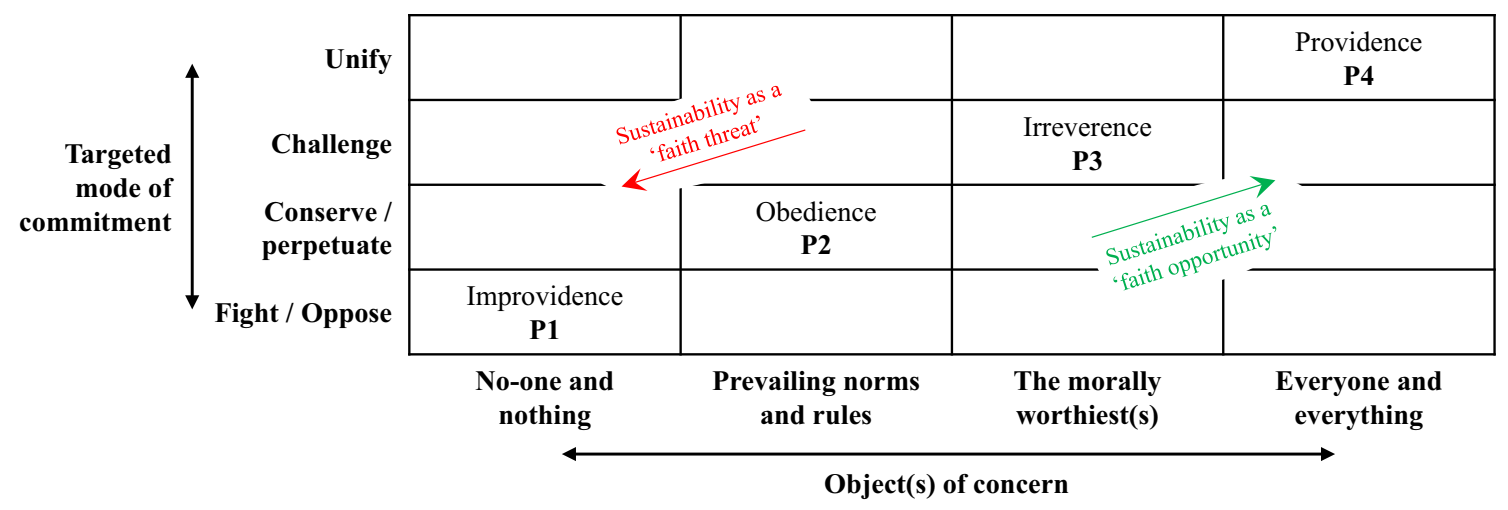

Fig. 1 A two-dimensional intentional faith development matrix for corporate sustainability 
widely used in psychological research, notably as a means to explore the cognitive, affective and behavioural factors aimed at positively relating to both the well-being of others and ecological welfare (e.g., Alisat et al. 2014; Carmeli et al. 2014, 2016; McAdams 2013; McAdams and Guo 2015; Urien and Kilbourne 2011). The theoretical discussions of generativity that took place are extended by Bradley (1997) in the idea that an individual's relation to the self and others depends on two process criteria: involvement (or the degree of active concern for the growth of oneself and others, later referred to as 'connectivity' in this article) and inclusivity (or the scope of one's caregiving activity, in terms of who and what is to be included or excluded).

The relational activities of a generative individual, in Bradley's model, are high in involvement and inclusivity. As McAdams and colleagues suggested, they induce an integration of instrumental (or agentic) and ethical (or communal) attitudes (Bradley 1997; McAdams et al. 1992, 1993). Urien and Kilbourne (2011) corroborate the argument that generativity as an ethical psychological state constantly interacts with self-enhancement and agentic motives-i.e., a need for the attainment of personal needs, goals and interests. The interaction of ethical and agentic motives is advanced to facilitate psychosocial adaptation (McAdams and Guo 2015)_including the strategic adaptability of managers (Carmeli et al. 2014, 2016). One may wonder if this aspect of generativity can explain a manager's psychological inclination to endorse a view of sustainability management as a cognitive process of adaptation that seeks alignment of sustainability response with business imperatives (Hahn et al. 2014), rather than as the product of a more substantive personal (or affective) connection with society for sustainability engagement (Alisat et al. 2014). The polarity between cognitive and affective elements is of equal concern to a stream of researchers who recognise the need for 'positive' relationality in the faith development equation (e.g., Kacela 2008; Kelcourse 2015). In particular, Kelcourse (2015) suggests a dual conception of faith as cognition and trust.

\section{Faith as Cognition}

The emphasis on cognition may be seen as the 'heritage' of a tradition of faith development scholarship that has incorporated insights from psychological determinism research, including aspects of Erikson's lifespan theory and subsequent generativity models (e.g., Bradley 1997; Fowler 1981, 2001; McDargh 2001). Cognitive activity is organised around the idea of individuals striving to construct meaning and formulate an understanding about particular experience(s) or events that occur in human life (Fowler 1981, 1991). The inclusion of cognition in the faith development process stresses the ability of individuals to act self-consciously, affirm their freedom of agency and preserve the ability to accept or reject given principles (Kacela 2008). They become active organisers of their experience (Kevany 2007). In Bradley's (1997) view, cognition notably performs as a conduit for satisfying personal goals or objectives, and less attention given to the needs of others. The tendency of corporate managers to be driven by their personal career ambitions and/or by their firm's profitability is a recurrent theme of business biographies from reputedly 'successful' corporate leaders. ${ }^{12}$ These biographies are replete with references to the demonstration of a bias towards an egotistic disregard of others (improvidence), a loyalty to one's group matched by hostility to other groups (obedience), or concentrating on short-term benefits and overlooking long-term (social) costs. In the case of sustainability management, this may translate into a manager's obedience to a firm's economic imperatives, implying the neglect of the social and environmental aspects of sustainability that do not contribute to these imperatives. The paradoxical and business case cognitive frames proposed by Hahn et al. (2014) seem to support the idea of a systematic search for alignments between business goals and sustainability response. Kegan (1994) argues that the use of cognition as an alignment or adaptive mechanism is likely to generate only marginal adjustments of an individual's thinking and feelings, as well as of his or her relation to others. The selective and calculative consideration of broader community needs that characterise the cognitive operations in which managers are involved (Hahn et al. 2014, 2015) may mean to neglect the deeper role of relationality (Kacela 2008) in shaping managers' potential for pro-sustainability involvement and inclusivity.

According to Kegan (1994), the search for meaning that is associated with faith can also trigger a cognitive process of socialisation, capable of fostering a change in consciousness rather than only marginal adjustments. The main idea is that individuals interacting with other social actors are involved in bringing inside of [themselves] the other's point of view. The most faithful individuals are those who make the other's point of view intrinsic to their own being (Kacela 2008). This element of faith development echoes a recent trend in corporate sustainability research conceiving of business actors as able to 'socialise' for shared value creation and sustainability-oriented innovation (Martinez et al. 2017). The process relies on (formal

\footnotetext{
12 One may notably refer to the 'lean and mean' culture created by Jack Welch at General Electrics (Welch and Byrne 2001), the brutal downsizings and massive layoffs led by Albert Dunlap at Sunbeam (Byrne 1999), or the tendency of Donald Trump to lead his numerous business ventures with reliance on instincts and a putative inclination for the generation of profits at all costs (Trump and Schwartz 1989).
} 
and/or informal) socially constructed dynamics that can be created between businesses and their stakeholders for sustainability gains. The resulting dynamics engage individuals who share a belief in sustainability (notably the existence of interdependencies between business and community needs), carry ideas, focus their energies and mobilise competences in joint projects. Socially connected and inclusive managers are therefore portrayed as able to understand (divergent) stakeholder perspectives, recognise the appropriateness of these perspectives and develop respectful and authentic relationships that make feasible collective choices and unified commitment to sustainability projects.

The (positive) relational aspects of faith that can be found in the cognitive process of socialisation are, however, rarely found in the business community (Kals and Maes 2012; Martinez et al. 2017). As implied above, business managers are typically portrayed as dependent on experience, and imbued with reliance on rational decisionmaking processes based on cognitive ordering, structuring and determinism. This is matched by the growing 'atrophy' of individual skills for (selfless) sharing, compassion and consideration, observed by Kevany (2007). The management of sustainability, viewed from this angle, is likely to be permeated with, and impaired by, elements from low phases of faith development (i.e., improvidence and obedience), characterised by 'rudimentary' relational skills.

\section{Faith as Trust}

Kelcourse's (2015) conception of faith as trust is an opportunity to extend the discussion to a more holistic understanding of relational faith development in the context of corporate sustainability. It conceives of trust as a red thread that links all our experiences of receptivity to self and to 'Others', and that is constituted in terms of two core elements: emotion and reciprocity.

The inclusion of emotion draws attention to the affective (emotional/psychodynamic) aspects of faith development. It adds feelings to experiences, and the meanings given to them, to produce complex concepts such as love, hate, anger and happiness. An individual's feeling of connectedness to others is partly determined by his or her emotional understanding of a given situation (Kelcourse 2015). Generativity and faith development scholars converge on the idea that the experience of an affective gap-such as those prompted by an 'imaginary anticipation of social and environmental damages': threat to one's life and health, uncertainty or helplessness (Degenhardt 2012, p. 135) - is likely to yield redemptive action by highly faithful individuals (e.g., Bornstein 2002; Fowler 2004; McAdams 2013, 2014; McAdams et al. 1993). Redemption (or in Fowler's (2004) words, the need for repentance) marks a transition from an emotionally negative scene to a positive outcome or attribution about the self. It is argued to constitute not only an important characteristic of effective leadership (McAdams 2014) but also an indicator of an individual's social engagement (McAdams and Guo 2015) and commitment to the well-being of future generations (McAdams 2013). By conceptualising their own lives as tales of redemption, managers are likely to experience phases of indignation or feelings of guilt about, e.g., insufficient sustainable behaviour for those who accept sustainability as a valuable goal (Douglas Creed et al. 2014; Kals and Maes 2012). Individuals manifesting elements of irreverence and providence are aware that sustainability problems exist and feel morally responsible to act in a corresponding way.

Cognitive emotion theory (e.g., Frijda 1993; Schwarz 2000) anticipates that feelings of guilt and responsibility may be exacerbated by the existence of discrepancies between experienced behaviours and moral concerns about sustainability. Managers may be forced to cognitively engage with their emotions (and perhaps seek adaptations and compromises) in the process of implementing sustainability in their organisations (Metcalf and Benn 2013). Affected individuals with redemptive qualities yet sustain the hope or confidence that is needed to weather short-term setbacks while reinforcing long-term commitments to improving the lives of others (McAdams and McLean 2013). Redemption - with its dependence on a manager's emotional affinity towards others and the environmentprovides the motivation to persevere in complex, nonlinear, cognitively demanding and (perhaps) chaotic environments (Metcalf and Benn 2013) that may characterise organisational change (Burnes 2005) and sustainability management (Espinosa and Porter 2011). If a firm's involvement in socially responsible projects may be prompted by a manager's redemptive activities, such as those (famously reported) of Ray Anderson from Interface (2001) or Anita Roddick (1991) from the Bodyshop, many socially responsible behaviours are in fact initiated because managers listen to market forces (Kinard et al. 2003). They are concerned about the environment, child labour and human rights because consumers care about these things-which is framed in this study as a pattern of obedience with little capacity for redemption. ${ }^{13}$

That managers with high emotional affinity towards sustainability are inclined to obtain a return on their commitment can, however, be included as an element in the process of relational faith development. I hereby refer to the element of reciprocity in the conception of faith as trust

\footnotetext{
13 This means for instance that Rosenblatt's (2000) reference to the business case for social responsibility as redemption can be considered erroneous.
} 
(Kelcourse 2015). The core idea of reciprocity is that trust is not exclusively regarded as a feeling or an emotional affinity. It also needs to be qualified by the one who is trusted and 'reveals him- or herself' (Kacela 2008). Processes of reciprocity reflect the involvement of individuals in mutual recognition of, and response to, the agency of the other person-which adds a salient interactional dimension to faith development. 'Morally convergent' individuals will tend to give and receive sympathy (Thurman 1979). They will establish a relational context in which emotions are understood so that the chances for spiritual companioning and long-term collaborative action are increased (Benefiel 2002). For example, corporate managers who identify with a specific centre of value, such as sustainability, may grow to understand the meaning of their faith through a commitment to establish relationships with members of the wider stakeholder community who are affected by, or somehow implicated in, sustainability issues. Mutual trust is nurtured according to the degree of 'positive' reciprocity (i.e., compassion, sympathy and companioning) that can be established between the actors involved. The emotional sympathy that may arise between actors of a reciprocal process determines the quality of their commitment to diversity and difference (Kacela 2008). It serves as a useful complement to the cognitive level of perspective change in emotional experiences of managers (Degenhardt 2012).

In the context of sustainability management, the notion of reciprocity is often discussed as a characteristic that drives the relationship between the firm and its legitimate stakeholders-i.e., the people and organisations who affect or are affected by the activities of the firm (Tapscott and Ticoll 2003). Lack of transparency and trust between these entities is highlighted as an important impediment to constructive dialogue, in spite of the reciprocal norms between firms and stakeholders that may exist, evolve and manifest over the years in the form of standard contracts, rules, procedures and codes of proper behaviour (Swärd 2016). These norms may guide reciprocity in early encounters (Hoppner and Griffith 2011) or even develop between partners through their interactions (Larson 1992). But they are unlikely to be effective in the process of building trust (and thus faith) for substantive sustainability engagement if they are not imbued with emotional affinities (sympathy and companioning) between the actors involved (Kals and Maes 2012).

\section{Synthesis: Towards an Integrative Model of Connectivity, Inclusivity, Emotional Affinity and Reciprocity}

In the above theoretical analysis, I interweaved elements from diverse faith development perspectives to explain how cognition influences a manager's relational activities in the context of faith development and how feelings and emotions play their part in shaping trust amongst management teams and stakeholders. One assumption drawn from intentional faith development theory is that managers can enact their freedom of agency, choosing whatever mode of commitment and object(s) of concern they deem relevant and valuable. Another assumption, drawn from generativity models and relational faith development theory, is that ethical concerns and agentic motives constantly interact to determine an individual's degrees of connectivity (or involvement) with, and inclusivity of, 'Others'. When examined as isolated variables that have an effect on faith orientation, as in Bradley's (1997) generativity model, connectivity and inclusivity are essentially assumed to represent cognitive processes of alignment, adaptation and socialisation. The incorporation of elements from the conception of faith as trust (e.g., Kacela 2008; Kelcourse 2015) provides for a more holistic perspective on faith development. It notably leads to the argument that, in the process of faith development, a manager's connectivity and inclusivity interact with his or her emotional affinity towards 'Others' (potentially resulting in redemptive activities) and the reciprocity he or she establishes with 'Others' (whether this is based on mutual sympathy, compassion or companioning). Therefore, four process criteria are proposed as operational aspects in a model of faith development for sustainability management: connectivity, inclusivity, emotional affinity and reciprocity.

Application of the model on corporate sustainability phenomena implies a focus on a manager's relational context, consisting of his or her interactions with other business agents (e.g., shareholders, executives, middle managers, employees) and with members of the wider stakeholder community who affect, or are affected by, a firm's activities. In line with Bradley (1997), the model anticipates that a manager can experience phases of relative selfishness or selflessness by including consideration of how he or she relates to the 'self' in the faith development process. The combination of process criteria contemplated in this study is presented in Fig. 2. Each phase of faith development generates scores on a continuum from high to low. The scores reflect hypotheses about the degrees of connectivity, inclusivity, emotional affinity and reciprocity that a manager is likely to demonstrate in his or her relation to the self, other business agents and members of the wider stakeholder community.

The breadth of the theoretical construct presented in Fig. 2 confronts corporate sustainability researchers with the challenge of measuring and validating any aspect of the model. In the following, the essential elements that will help researchers define appropriate measurement methods are specified; and hypotheses that will guide future research are formulated. 


\begin{tabular}{|l|c|c|c|c|c|c|c|c|c|c|c|}
\multicolumn{10}{c|}{ FAITH AS COGNITION } \\
\cline { 2 - 17 }
\end{tabular}

Fig. 2 Relational faith development: process criteria of inclusivity, connectivity, emotional affinity and reciprocity, and resulting faith orientations

The process criterion of connectivity reflects a manager's actual engagement in sustainability. Generativity theory entails that connectivity can be measured in terms of a manager's activities aimed at contributing to his or her own growth, to the care of others and to one's productive efforts (e.g., Bradley 1997; Kotre 1984; McAdams et al. 1992; Snarey 1993). Highly connected managers (e.g., providence) will demonstrate an inclination for sharing skills and knowledge with a diversity of social actors. They will take opportunities to participate in pro-social activities, sustainability projects and possibly volunteer work. An 'ideal' level of connectivity involves managers, their organisations and legitimate stakeholders in reinforcing and balancing feedback processes that have an impact on sustainability progress. Managers with low connectivity will experience relatively distant and perfunctory relations to 'Others', and possibly to the self (e.g., obedience). Combining elements from the above theoretical analysis and Table 2, the following working hypothesis, and subhypotheses, are proposed:

H1 As measures of connectivity increase, managers will move to higher phases of faith development and will be more substantively engaged in sustainability.

H1a Provident managers will seek unity of everyone and everything. They score high on all dimensions of connectivity.

H1b Irreverent managers will be independent and mainly concerned about self-efficacy. They score high on connectivity with the self, and low on other dimensions.

H1c Obedient managers will be dependent on the norms that prevail in their firms to guide their actions.

They score high on connectivity with other business agents, and low on other dimensions.
H1d Improvident managers will be self-absorbed. They score high on connectivity with the self, and low on other dimensions.

The process criterion of inclusivity reflects the extent to which a manager's moral consideration (or concern) includes or excludes others. It adds an element of moral selectivity to the relational dynamics that characterise an individual's degree of connectivity. Inclusivity can be measured in terms of a manager's generative potential, in line with Erikson's (1982) notions of care and rejectivity. It reflects the scope of care and the question of whether one's caring attention is focussed on personal or communal needs and concerns (Bradley 1997). Highly inclusive managers (e.g., providence) will long for a society in which honesty and openness would prevail. They will believe that all living things have value independent of their usefulness to human purposes and will feel that everyone (all social actors and institutions) and everything (e.g., animals, environment) is connected. Therefore, they will include everyone and everything in their concern, not just their institutions like the obedient managers, or just themselves like the improvident managers. Low inclusivity generates the rejection or suppression of 'Others', and a consideration of the self that can be negative when moral attachments are weak (improvidence), or positive when moral integrity is involved (irreverence). Combining elements from the above theoretical analysis and Table 2, the following working hypothesis, and sub-hypotheses, are proposed:

H2 As measures of inclusivity increase, managers will move to higher phases of faith development and will be more substantively engaged in sustainability. 
H2a Provident managers score high on all dimensions of inclusivity.

H2b Irreverent managers will be concerned about moral integrity. They score high on inclusivity of the self and are dependent on their moral judgment concerning other dimensions.

H2c Obedient managers will be concerned about adapting their behaviours to fit in a specific social context such as the firm. They score high on inclusivity of other business agents, and low on other dimensions.

H2d Improvident managers will be concerned about satisfying their own desires and are not able to care for anything or anyone else. They score high on inclusivity of the self, and low on other dimensions.

The process criterion of emotional affinity reflects a manager's affection towards others, and particularly towards sustainability issues that affect both the firm and its stakeholders. Sustainability can indeed constitute a source of emotional affinity because it may yield processes that link managers and other social actors in a 'relation-tothe-transcendent', as well as in a common quest to address an affective gap or to establish a sense of security in situations of uncertainty (Coyle 2011; Degenhardt 2012; Kals and Maes 2012), inciting individuals to reach out to others (Kacela 2008). Emotional affinity can be measured in terms of a manager's demonstration of sensitivity and affection towards the self, other business agents and members of the wider stakeholder community. Managers with high emotional affinity (providence) will demonstrate the redemptive potential to address emergent affective gaps. Low emotional affinity equates to deficient emotional attachment structure, maturity and caring capacity. Combining elements from the above theoretical analysis and Table 2, the following working hypothesis, and sub-hypotheses, are proposed:

H3 As measures of emotional affinity increase, managers will move to higher phases of faith development and will be more substantively engaged in sustainability.

H3a Provident managers score high on all dimensions of emotional affinity.

H3b Irreverent managers will be sensitive to a gap in their moral integrity and self-efficacy. They score high on emotional affinity with the self, and low on other dimensions.

H3c Obedient managers will be sensitive to a gap in external authority. They score high on emotional affinity with other business agents, and low on other dimensions.
H3d Improvident managers will be affectively immature (therefore unstable) and lack sensitivity to 'Others'. They score low on emotional affinity with other business agents and members of the wider stakeholder community, and are relatively unpredictable regarding the 'self' dimension.

The process criterion of reciprocity reflects the extent to which a manager is rewarded for responding to the needs and concerns of 'Others', mainly in the form of a positive emotional (and relational) stimulus. It implies the development of a give-and-take relationship (Kacela 2008) in which each knows that one's effort to respond to a need to be cared for is one with our concern to be cared for ourselves. Actions that are somehow beneficial to self generate an emotional stimulus that incites individuals to act positively in return (Bosse et al. 2009; Swärd 2016). Reciprocity can be measured in terms of a manager's capacity to perform as a compassionate listener and to develop relationships of common sympathy, mindfulness and spirit with 'Others'. According to Krebs, Rieunier, and Urien (2015), one aspect that may motivate reciprocity is the desire for posterity-i.e., the idea of being commemorated by future generations and society, and to achieve symbolic immortality. Managers with high reciprocity (e.g., providence) will demonstrate a strong motivation to be involved in (and a passion for) communal projects and activities. Managers with low reciprocity will privilege individualised experiences and will therefore act in isolation from 'Others'. Combining elements from the above theoretical analysis and Table 2, the following working hypothesis, and sub-hypotheses, are proposed:

H4 As measures of reciprocity increase, managers will move to higher phases of faith development and will be more substantively engaged in sustainability.

H4a Provident managers score high on all dimensions of reciprocity.

H4b Irreverent managers will seek motivation and reward in their passion about their internal quest for the 'truth', as well as their commitment to the morally worthiest cause. They score high on reciprocity with the self, and low on other dimensions.

H4c Obedient managers will seek motivation and reward in the emotional (and relational) stimuli they receive from an external source of authority. They score high on reciprocity with other business agents, and low on other dimensions.

H4d Improvident managers are immune from compassion and do not seek rewarding relations. They score low on all dimensions of reciprocity. 
Overall, the hypotheses are constructed as statements of expectations about the causal relationship between the phases of faith development and commitment to sustainability, with the process criteria of connectivity, inclusivity, emotional affinity and reciprocity as parameters determining 'fitness'. They are incorporated in a conceptual framework of faith development for sustainability management as a basis for further deductive research in this domain. Each working hypothesis includes a provisional explanatory statement that specifies conditions under which sustainability engagement will be optimal. These statements are supported by four sub-hypotheses formulated as analytical and theoretically grounded statements. For example, the sub-hypotheses describe the provident manager as high in connectivity, inclusivity, emotional affinity and reciprocity, in line with the definition of providence proposed in this article (cf. Table 2). The provisional hypothesis is that he or she will be more substantively engaged in sustainability, as opposed to irreverent, obedient and improvident managers who will perform at a lower level of sustainability engagement without the same faith attributes. Future research may be designed to include methods of evidence collection that either confirm or contradict aspects of these hypotheses, and consolidate our understanding of the faith attributes of managers that shape a firm's disposition towards sustainability. Four main characteristics of this article can be highlighted that support the prescriptive ability (and applicability thereof) of faith development theory.

Firstly, the article specifies the context within which the theory applies by referring to the relational environment of a manager willing (or somehow incited) to engage in sustainability. Many organisational activities across institutional sectors (public or private) are structured and managed according to strict business routines. Managers must often deal with a multitude of pressures and tensions inherent in the dual objective of maintaining economic viability of these activities and considering their impact on wider society. They are likely to be involved in processes of faith development that constantly challenge their relations to self, other business agents and members of the wider stakeholder community (in ways that are captured in Fig. 2).

Secondly, the article can serve as an aid to managers in firms that invest resources to develop sustainability capabilities, but where the faith potential is not fully realised, to more fully realise this potential. Managers can use faith development theory to more completely understand the type of relations that can enhance faith (and engagement thereof) in sustainability, help them use this understanding to evaluate the faith attributes that their firms may possess, and then exploit those attributes that have the potential to improve sustainability performance. By extension, the model can help firms nurture faith attributes as part of their continuous efforts to develop sustainability capabilities.

Thirdly, the elements that are uncovered in this article to define the four process criteria of connectivity, inclusivity, emotional affinity and reciprocity can serve as indicators of what parameters can be tested, and what types of data are needed, in future empirical applications of faith development theory. The article further provides interested researchers with empirically testable assertions of the form, managers manifesting elements of providence characterised by high connectivity, high inclusivity, high emotional affinity and high reciprocity will be more substantively engaged in sustainability than managers manifesting elements of improvidence, obedience and irreverence.

Finally, the article embraces a view of faith development as a dynamic, nonlinear and socially constructed process that is critically shaped by the actions of individuals who hold within themselves the capacity to navigate between elements of more than one phase of faith development. It is expected that each study context will reveal the unique combination of elements from several phases reflected in a manager's experience, rather than a manager's linear conformity with elements of one phase. Instead of focusing on the state of a manager's faith attributes at a specific point in time, faith development is arguably more fittingly studied by comparing the state of a manager's faith attributes at one time with the state of these attributes at a later time, and by identifying the implications of change for the actual practice of sustainability. One of the advantages of this 'evolutionary' approach is that it is possible to study the dynamics of faith development by avoiding the potential fallacy of portraying certain managers (or organisations) either as morally culpable or as sustainability champions based on the analysis of one-off events.

\section{Conclusion}

A core concern in this article is with pressures for change towards more sustainable business practices or 'threats' to the maintenance of a faith position that places business interests before wider societal interests, with these experienced as negative or positive. The business community has generally attempted to give unity and permanence to values of productivity and profits. That has tended to yield to the expression of overly determinist patterns of management behaviour that promote status quo in management thinking and neglect some essential micro-level catalyst for sustainability progress, including faith. Contrary to the emphasis in institutional theory on the cultural persistence and endurance of institutionalised organisational behaviours, faith development theory assumes that the objects 
of concern and modes of commitment of managers undergo a variable developmental process. In particular, under elevated faith dispositions, institutionalised (and perhaps unsustainable) behaviours are highly susceptible to dissipation, rejection or replacement (Oliver 1992). The present model proposes that high levels of connectivity, inclusivity, emotional affinity and reciprocity amongst business decision-makers, management teams and members of the wider stakeholder community generate a climate of trust that renders unlikely the occurrence of social and environmental misconduct. Managers involved in these processes are able to identify with diverse representatives of the stakeholder community and make their variant manifestations, needs and concerns intrinsic to their own being. ${ }^{14}$ The outcome is both an enriched understanding of the 'faith dynamics' that are at work at management levels and an expanded scope of moral considerations relevant to the view of economic and human activities as inextricably linked with social and ecological systems (Gladwin et al. 1995; Harris and Freeman 2008).

By considering faith as the carrier of both cognitive and emotional factors, the model contributes to the literature on the psychological drivers of sustainability management that has largely privileged cognitive explanations (e.g., Hahn et al. 2014; Kaplan 2011; Morner et al. 2010; Nadkarni and Barr 2008; Smith and Tushman 2005; Thomas et al. 1993). It highlights the limitations of traditional socio-cognitive accounts of economic (and moral) decision-making by drawing attention to the 'humanist' nature of many business managers who engage in sustainability and demonstrate caring abilities in this endeavour. Anecdotally, the disposition of provident individuals to orient their faith towards a more harmonious system of connections between business, natural and social constituencies might in some ways find its roots in the old ages (about ten centuries ago) when humans had a mystic relationship with the nature, and all forms of lives were both generously venerated and humbly feared. Interestingly, generosity and humility are key tenets of the contemporary philosophy advocated by Lévinas (1998), namely relational ethics, that questions the authenticity, self-obsession and presumed immunity of individual agents acting on behalf of business organisations.

It is hoped that the model developed in this article, and the research hypotheses it contains, will contribute to bring an end to the general climate of 'apostasy' and spiritual opacity in the management context by illuminating our search for a process of faith development that connects with an increasingly complex understanding of the role of business in society. In various ways, the general awareness

\footnotetext{
14 This phenomenon is notably discussed by proponents of an ethic of care (Noddings, 1984, 2002; Tronto, 1993).
}

of the human proclivity to submit to low ethical standards in the corporate world acts to legitimise the espousal and usefulness of a (redemptive) faith development theory in management education and formation.

\section{Compliance with Ethical Standards}

Conflict of interest The author, Fabien Martinez, declares that he has no conflict of interest.

Ethical Approval This article does not contain any studies with human participants or animals performed by the author.

Open Access This article is distributed under the terms of the Creative Commons Attribution 4.0 International License (http://crea tivecommons.org/licenses/by/4.0/), which permits unrestricted use, distribution, and reproduction in any medium, provided you give appropriate credit to the original author(s) and the source, provide a link to the Creative Commons license, and indicate if changes were made.

\section{References}

Aguilera, R. V., Rupp, D. E., Williams, C. A., \& Ganapathi, J. (2007). Putting the $\mathrm{S}$ back in corporate social responsibility: A multilevel theory of social change in organizations. Academy of Management Review, 32(3), 836-863.

Alisat, S., Norris, J. E., Pratt, M. W., Matsuba, M. K., \& McAdams, D. P. (2014). Caring for the earth: Generativity as a mediator for the prediction of environmental narratives from identity among activists and nonactivists. Identity, 14(3), 177-194.

Anderson, R. C. (2001). Spiritual wisdom for a new milenium. Eugene, Oregon: Wipf and Stock.

Arjoon, S. (2005). Corporate governance: An ethical perspective. Journal of Business Ethics, 61(4), 343-352.

Atchley, R. (1997). Everyday mysticism: Spiritual development in later adulthood. Journal of Adult Development, 4(2), 123-134.

Atia, M. (2012). "A way to paradise": Pious neoliberalism, Islam, and faith-based development. Annals of the Association of American Geographers, 102(4), 808-827.

Avolio, B. J., \& Gardner, W. L. (2005). Authentic leadership development: Getting to the root of positive forms of leadership. The Leadership Quarterly, 16(3), 315-338.

Bass, B. M., \& Steidlmeier, P. (1999). Ethics, character, and authentic transformational leadership behavior. The Leadership Quarterly, $10(2), 181-217$.

Benefiel, M. (2002). The second half of the journey: Companioning organizations through spiritual transformation. Academy of Management Proceedings, 2002(1), B1-B6.

Bornstein, E. (2002). Developing faith: Theologies of economic development in Zimbabwe. Journal of Religion in Africa, 32(1), 4-31.

Bosse, D. A., Phillips, R. A., \& Harrison, J. S. (2009). Stakeholders, reciprocity, and firm performance. Strategic Management Journal, 30(4), 447-456.

Boudens, C. J. (2005). The story of work: A narrative analysis of workplace emotion. Organization Studies, 26(9), 1285-1306.

Bradley, C. L. (1997). Generativity-stagnation: Development of a status model. Developmental Review, 17(3), 262-290.

Brammer, S., Williams, G., \& Zinkin, J. (2007). Religion and attitudes to corporate social responsibility in a large crosscountry sample. Journal of Business Ethics, 71(3), 229-243. 
Burnes, B. (2005). Complexity theories and organizational change. International Journal of Management Reviews, 7(2), 73-90.

Burnes, B., \& By, R. T. (2011). Leadership and change: The case for greater ethical clarity. Journal of Business Ethics, 108(2), 239-252.

Byrne, J. A. (1999). Chainsaw: The notorious career of Al Dunlap in the era of profit-at-any-price. New York: Harper Business.

Carmeli, A., Jones, C. D., \& Binyamin, G. (2014). Relational underpinning of strategic adaptability: The power of caring and generativity. Academy of Management Proceedings, 2014(1), 14751.

Carmeli, A., Jones, C. D., \& Binyamin, G. (2016). The power of caring and generativity in building strategic adaptability. Journal of Occupational and Organizational Psychology, 89(1), 46-72.

Clore, V., \& Fitzgerald, J. (2002). Intentional faith: An alternative view of faith development. Journal of Adult Development, 9(2), 97-107.

Cooper, C. (2015). Accounting for the fictitious: A Marxist contribution to understanding accounting's roles in the financial crisis. Critical Perspectives on Accounting, 30, 63-82.

Coyle, A. (2011). Critical responses to faith development theory: A useful agenda for change? Archive for the Psychology Religion, 33(3), 281-298.

Crotty, J. (2009). Structural causes of the global financial crisis: a critical assessment of the 'new financial architecture'. Cambridge Journal of Economics, 33(4), 563-580.

Davies, B., \& Harré, R. (1990). Positioning the discursive production of selves. Journal for the Theory of Social Behaviour, 20(1), 43-63.

Degenhardt, L. (2012). Sustainable lifestyle pioneers. In P. Schmuk \& W. P. Schultz (Eds.), Psychology of sustainable development (pp. 123-148). New York, NY: Springer Science \& Business Media.

Dehler, G. E., \& Welsh, M. A. (1994). Spirituality and organizational transformation: Implications for the new management paradigm. Journal of Managerial Psychology, 9(6), 17-26.

DiMaggio, P. J., \& Powell, W. W. (1983). The iron cage revisited: Institutional isomorphism and collective rationality in organizational fields. American Sociological Review, 48(2), 147-160.

Douglas Creed, W. E., DeJordy, R., \& Lok, J. (2014). Myth to work by: Redemptive self-narratives and generative agency for organizational change. In P. Tracey, N. Phillips, \& M. Lounsbury (Eds.), Religion and organization theory (Vol. 41, pp. 111-158). Bingley: Emerald Group.

Eisenhardt, K. M., \& Zbaracki, M. J. (1992). Strategic decision making. Strategic Management Journal, 13(S2), 17-37.

Elkington, J. (1999). Triple bottom line revolution-reporting for the Third Millenium. Australian CPA, 69(10 and 11), pp. 75-77.

Elkington, J. (2004). Enter the triple bottom line. In A. Henriques \& J. Richardson (Eds.), The triple bottom line: Does it all add up? Assessing the sustainability of business and CSR (pp. 1-16). London: Earthscan.

Erikson, E. H. (1950). Childhood and society. New York, NY: W. W. Norton adn Company Inc.

Erikson, E. H. (1964). Insight and responsibility. London: Faber \& Faber.

Erikson, E. H. (1974). Dimensions of a new identity. New York: Norton.

Erikson, E. H. (1982). The life cycle completed. New York: W. W. Norton \& Company.

Espinosa, A., \& Porter, T. (2011). Sustainability, complexity and learning: insights from complex systems approaches. The Learning Organization, 18(1), 54-72.

Fowler, J. W. (1981). Stages of faith: The psychology of human development and the quest for meaning. New York: Harper \& Row.
Fowler, J. W. (1991). Stages in faith consciousness. New Directions for Child and Adolescent Development, 1991(52), 27-45.

Fowler, J. W. (2001). Faith development theory and the postmodern challenges. The International Journal for the Psychology of Religion, 11(3), 159-172.

Fowler, J. W. (2004). Faith development at 30: Naling the challenges of faith in a new millenium. Religious Education, 99(4), 405-421.

Friedman, M. (1953). Essays in positive economics. Chicago: University of Chicago Press.

Frijda, N. (1993). The place of appraisal in emotion. Special issue: Appraisal and beyond: The issues of cognitive determinants of emotion. Cognition and Emotion, 7, 357-387.

Fry, L. W. (2003). Toward a theory of spiritual leadership. The Leadership Quarterly, 14(6), 693-727.

George, W. (2003). Authentic leadership: Rediscovering the secrets to creating lasting value. San Francisco: Jossey Bass.

Ghoshal, S. (2005). Bad management theories are destroying good management practices. Academy of Management Learning \& Education, 4(1), 75-91.

Gladwin, T. S. (2011). Limits on business and the environment under capitalism. In A. J. Hoffman \& T. Bansal (Eds.), The Oxford handbook of business and the environment Oxford. England: Oxford University Press.

Gladwin, T. S., Kennelly, J., \& Krause, T. (1995). Shifting paradigms for sustainable development: Implications for management theory and research. Academy of Management Review, 20(4), 878-907.

Gond, J.-P., \& Crane, A. (2010). Corporate social performance disoriented: Saving the lost paradigm? Business and Society, 49(4), 677-703.

Hahn, T., Figge, F., Pinkse, J., \& Preuss, L. (2010). Trade-offs in corporate sustainability: You can't have your cake and eat it. Business Strategy and the Environment, 19(4), 217-229.

Hahn, T., Pinkse, J., Preuss, L., \& Figge, F. (2014). Cognitive frames in corporate sustainability: Managerial sensemaking with paradoxical and business case frames. Academy of Management Review, 39(4), 463-487.

Hahn, T., Pinkse, J., Preuss, L., \& Figge, F. (2015). Tensions in corporate sustainability: Towards an integrative framework. Journal of Business Ethics, 127(2), 297-316.

Hahn, T., Pinkse, J., Preuss, L., \& Figge, F. (2016). Ambidexterity for corporate social performance. Organization Studies, 37(2), $213-235$.

Harris, J. D., \& Freeman, R. E. (2008). The impossibility of the separation thesis: A response to Joakim Sandberg. Business Ethics Quarterly, 18(4), 541-548.

Hart, C. W. (2007). J. Robert Oppenheimer: A faith development portrait. Journal of Religion and Health, 47(1), 118-128.

Harvey, J. (2015). A new ethics, a new discourse, a new economy. In P. G. Brown \& P. Timmerman (Eds.), Ecological economics for the anthropocene: An emerging paradigm (pp. 318-356). New York: Columbia University Press.

Haugh, H. M., \& Talwar, A. (2010). How do corporations embed sustainability across the organization? Academy of Management Learning \& Education, 9(3), 384-396.

Hawken, P. (1994). The Ecology of commerce: A declaration of sustainability. New York: HarperBusiness.

Healey, M. P., Vuori, T., \& Hodgkinson, G. P. (2015). When teams agree while disagreeing: Reflexion and reflection in shared cognition. Academy of Management Review, 40(3), 399-422.

Helfat, C. E., \& Peteraf, M. A. (2015). Managerial cognitive capabilities and the microfoundations of dynamic capabilities. Strategic Management Journal, 36(6), 831-850.

Hemingway, C. A., \& Maclagan, P. W. (2004). Managers' personal values as drivers of corporate social responsibility. Journal of Business Ethics, 50(1), 33-44. 
Herman, S. W., \& Schaefer, A. G. (Eds.). (2001). Spiritual goods: faith traditions and the practice of business. http://www.pdenet. org/collection-anonymous/browse?fp=spiritgds \&fq=spiritgds\% 2FSpiritual\%20Goods\%3A\%20Faith\%20Traditions\%20and\% 20the $\% 20$ Practice $\% 20$ of $\% 20$ Business\%2F: Philosophy Documentation Center.

Heywood, D. (2008). Faith development theory: A case for paradigm change. Journal of Beliefs \& Values, 29(3), 263-272.

Hoare, C. H. (2001). Erikson on development in adulthood: New insights from the unpublished papers. New York: Oxford University Press.

Hoffman, W. M. (1986). What is necessary for corporate moral excellence? Journal of Business Ethics, 5(3), 233-242.

Hopkins, M. S. (2009). Sustainability and competitive advantage. MIT Sloan Management Review, 51(1), 19-26.

Hoppner, J. J., \& Griffith, D. A. (2011). The role of reciprocity in clarifying the performance payoff of relational behavior. Journal of Marketing Research, 48(5), 920-928.

Immink, G. (2005). Faith: A practical theological reconstruction. Cambridge: William B. Eerdmans.

Jardine, M. M., \& Viljoen, H. G. (1992). Fowler's theory of faith development: An evaluative discussion. Religious Education, 87(1), 74-85.

Johnston, L. F. (2014). Sustainability as a global faith? The religious dimensions of sustainability and personal risk. Journal of the American Academy of Religion, 82(1), 47-69.

Judge, W. Q., \& Douglas, T. J. (2013). Entrepreneurship as a leap of faith. Journal of Management, Spirituality \& Religion, 10(1), 37-65.

Kacela, X. (2008). Seasoned faith: Relationality, practice and community. Fort Worth, TX: Brite Divinity School.

Kahn, W. A. (1990). Psychological conditions of personal engagement and disengagement at work. The Academy of Management Journal, 33(4), 692-724.

Kals, E., \& Maes, J. (2012). Sustainable development and emotions. In P. Schmuk \& W. P. Schultz (Eds.), Psychology of sustainable development (pp. 97-122). New York, NY: Springer Science \& Business Media.

Kaplan, S. (2011). Research in cognition and strategy: Reflections on two decades of progress and a look to the future. Journal of Management Studies, 48(3), 665-695.

Kegan, R. (1982). The evolving self: Problem and process in human development. Cambridge, MA: Harvard University Press.

Kegan, R. (1994). In over our heads. Cambridge, MA: Harvard University Press.

Kelcourse, F. B. (Ed.). (2015). Human development and faith: Lifecycle stages of body, mind, and soul (2nd ed.). St. Louis, MO: Chalice Press.

Kevany, K. D. (2007). Building the requisite capacity for stewardship and sustainable development. International Journal of Sustainability in Higher Education, 8(2), 107-122.

Kinard, J., Smith, M. E., \& Kinard, B. R. (2003). Business executives' attitudes toward social responsibility: Past and present. American Business Review, 21(2), 87.

King, J. E. (2008). (Dis)missing the obvious: Will mainstream management research ever take religion seriously? Journal of Management Inquiry, 17(3), 214-224.

Kohlberg, L. (1981). The development of modes of thinking and choices in years 10-16. (Ph.D.), University of Chicago.

Kotre, J. (1984). Outliving the self: Generativity and the interpretation of lives. Baltimore: Johns Hopkins University Press.

Krebs, A., Rieunier, S., \& Urien, B. (2015). Generativity: Its role, dimensions and impact on cultural organizations in France. International Journal of Arts Management, 17(3), 28-45.

Kuhnert, K. W., \& Lewis, P. (1987). Transactional and transformational leadership: A constructive/developmental analysis. Academy of Management Review, 12(4), 648-657.
Larson, A. (1992). Network dyads in entrepreneurial settings: A study of the governance of exchange relationships. Administrative Science Quarterly, 37(1), 76-104.

Lévinas, E. (1998). Otherwise than being or beyond essence (A. Lingis, Trans.). Pittsburgh: Duquesne University Press.

Lonergan, B. J. (1970). Religious commitment. In J. Papin (Ed.), Villanova University Symposium: The pilgrim people: A vision with hope (Vol. 4, pp. 45-69). Villanova, PA: Villanova University Press.

Lonergan, B. J. (1972). Method in theology. New York: Seabury.

Luthans, F., \& Avolio, B. J. (2003). Authentic leadership development. In K. S. Cameron, J. E. Dutton, \& R. E. Quinn (Eds.), Positive organizational scholarship: Foundations of a new discipline (pp. 241-258). San Francisco: Berrett-Koehler.

Luthans, F., \& Youssef, C. M. (2007). Emerging positive organizational behavior. Journal of Management, 33(3), 321-349.

Mahoney, J. T., Huff, A. S., \& Huff, J. O. (1994). Toward a new social contract theory in organization science. Journal of Management Inquiry, 3(2), 153-168.

Marshall, A., Baden, D., \& Guidi, M. (2013). Can an ethical revival of prudence within prudential regulation tackle corporate psychopathy? Journal of Business Ethics, 117(3), 559-568.

Martinez, F., O'Sullivan, P., Smith, M., \& Esposito, M. (2017). Perspectives on the role of business in social innovation. Journal of Management Development, 36(5), In press.

McAdams, D. P. (2013). The positive psychology of adult generativity: Caring for the next generation and constructing a redemptive life. In J. D. Sinnott (Ed.), Positive psychology: Advances in understanding adult motivation (pp. 191-205). New York, NY: Springer.

McAdams, D. P. (2014). Leaders and their life stories: Obama, Bush, and narratives of redemption. In G. R. Goethals, S. T. Allison, R. M. Kramer, \& D. M. Messick (Eds.), Conceptions of leadership: Enduring ideas and emerging insights (pp. 146-165). US: Palgrave Mcmillan.

McAdams, D. P., de St. Aubin, E., \& Logan, R. L. (1992). A theory of generativity and its assessment through self-report, behavioural acts, and narrative themes in autobiography. Journal of Personality and Social Psychology, 62(6), 1003-1015.

McAdams, D. P., de St. Aubin, E., \& Logan, R. L. (1993). Generativity among young, midlife, and older adults. Journal of Personality and Social Psychology, 8(2), 221-230.

McAdams, D. P., \& Guo, J. (2015). Narrating the generative life. Psychological Science, 26(4), 475-483.

McAdams, D. P., \& McLean, K. C. (2013). Narrative identity. Current Directions in Psychological Science, 22(3), 233-238.

McDargh, J. (2001). Faith development theory and the postmodern problem of foundations. The International Journal for the Psychology of Religion, 11(3), 185-199.

Meera, S. R., \& Bonin, S. (2014). From 'management by materialism' to 'management by spiritual wisdom'. International Journal of Business and Emerging Markets, 6(1), 71-82.

Metcalf, L., \& Benn, S. (2013). Leadership for sustainability: An evolution of leadership ability. Journal of Business Ethics, 112(3), 369-384.

Miller, D. W., Ngunjiri, F. W., \& Fernandez, D. A. (2013). Leadership views on Corporate Chaplains: Business, sociocultural, and spiritual justifications. Academy of Management Proceedings, 2013(1), 14864.

Minkes, A. L., Small, M. W., \& Chatterjee, S. R. (1999). Leadership and business ethics: Does it matter? Implications for management. Journal of Business Ethics, 20(4), 327-335.

Morner, M., Renger, E.-M., \& Thiele, R. V. (2010). Unravelling the human side of the board: the role of motivational and cognitive compatibility in board decision making. International Journal of Business Governance and Ethics, 5(4), 323-342. 
Nadkarni, S., \& Barr, P. S. (2008). Environmental context, managerial cognition, and strategic action: An integrated view. Strategic Management Journal, 29, 1395-1427.

Niebuhr, H. R. (1960). Radical monotheism and Western culture. New York: Harper and Row.

Noddings, N. (1984). Caring. Berkeley: University of California Press.

Noddings, N. (2002). Starting at home. Berkeley: University of California

Oliver, C. (1992). The antecedents of deinstitutionalization. Organization Studies, 13(4), 563-588.

Pache, A.-C., \& Santos, F. (2013). Inside the hybrid organization: Selective coupling as a response to competing institutional logics. Academy of Management Journal, 56(4), 972-1001.

Paquet, G. (1998). Evolutionary cognitive economics. Information Economics and Policy, 10(3), 343-357.

Parker, M. (1992). Post-modern organizations or postmodern organization theory? Organization Studies, 13(1), 001-017.

Peck, M. S. (1987). A different drum: Community making and peace. New York, NY: Touchstone.

Philippe, D., \& Bansal, P. (2013). Embedding environmental actions in time and space: The evolution of sustainability narratives. Academy of Management Proceedings, 2013(1), 14098.

Piaget, J. (1967). Six Psychological Studies. New York: Random House.

Porrit, J. (2009). Living within our means: Avoiding the ultimate recession. London: Forum for the Future.

Redman, C. (2013). Agentive roles, rights and duties in a technological era. In R. Harré \& F. Moghaddam (Eds.), The psychology of friendship and enmity: Relationships in love, work, politics, and war (pp. 246-264). New York: NOVA Science Publishers.

Reichers, A. E. (1985). A review and reconceptualization of organizational commitment. Academy of Management Review, 10(3), 465-476.

Rich, B. L., Lepine, J. A., \& Crawford, E. R. (2010). Job engagement: Antecedents and effects on job performance. Academy of Management Journal, 53(3), 617-635.

Robbins, P., Hintz, J., \& Moore, S. A. (2010). Environment and Society. Chichester: Wiley-Blackwell.

Robert Mitchell, J., Shepherd, D. A., \& Sharfman, M. P. (2011). Erratic strategic decisions: when and why managers are inconsistent in strategic decision making. Strategic Management Journal, 32(7), 683-704. doi:10.1002/smj.905.

Roddick, A. (1991). Body and soul: Profits with principles, the amazing success story of Anita Roddick \& the Body Shop. New York: Crown.

Roome, N., \& Louche, C. (2016). Journeying toward business models for sustainability: A conceptual model found inside the black box of organisational transformation. Organization \& Environment, 29(1), 11-35.

Rosenblatt, R. (2000). Redemption: It's good for business. Time, 155(21), 160.

Rositon, H. (1994). Conserving natural value. New York: Columbia University Press.

Sai Manohar, S., \& Pandit, S. (2014). Core values and beliefs: A study of leading innovative organizations. Journal of Business Ethics, 125(4), 667-680.

Schwarz, N. (2000). Emotion, cognition, and decision making. Cognition and Emotion, 14(4), 433-440.

Secchi, D. (2007). Utilitarian, managerial and relational theories of corporate social responsibility. International Journal of Management Reviews, 9(4), 347-373.

Selman, R. L. (1976). The development of social-cognitive understanding: A guide to educational and clinical practice. In T. Lickona (Ed.), Man and morality (pp. 299-317). New York, NY: Holt, Rinehart \& Wilson.
Singer, A. E. (2016). Corporate moral agency as an epistemological organizing principle. Human Systems Management, 35(1), $65-77$.

Smith, A. (2002). The theory of moral sentiments. Cambridge: Cambridge University Press.

Smith, W. K., \& Lewis, M. W. (2011). Toward a theory of paradox: A dynamic equilibrium model of organizing. Academy of Management Review, 36(2), 381-403.

Smith, W. K., \& Tushman, M. L. (2005). Managing strategic contradictions: A top management model for managing innovation streams. Organization Science, 16(5), 522-536.

Snarey, J. (1993). How fathers care for the next generation. Cambridge, MA: Harvard University Press.

Speth, J. G. (2009). The bridge at the end of the world: Capitalism, crisis, and crossing from crisis for sustainability. New haven, CT: Yale University Press.

Starik, M., \& Kanashiro, P. (2013). Toward a theory of sustainability management: Uncovering and integrating the nearly obvious. Organization \& Environment, 26(1), 7-30.

Sullivan, A., \& Sheffrin, S. M. (2003). Economics: Principles in action. Upper Saddle River, NJ: Pearson Prentice Hall.

Swanson, D. L. (1999). Toward an integrative theory of business and society: a research strategy for corporate social performance. Academy of Management Review, 24(3), 506-521.

Swanson, D. L. (2014). Embedding CSR into corporate culture: Challenging the executive mind. New York, NY: Palgrave Macmillan.

Swärd, A. (2016). Trust, reciprocity, and actions: The development of trust in temporary inter-organizational relations. Organization Studies, 37(12), 1841-1860.

Tapscott, D., \& Ticoll, D. (2003). The naked corporation: How the age of transparency will revolutionize business. New York, NY: Free Press.

Thomas, J. B., Clark, S. M., \& Gioia, D. A. (1993). Strategic sensemaking and organizational performance: Linkages among scanning, interpretation, action, and outcomes. Academy of Management Journal, 36(2), 239-270.

Thurman, H. (1979). With head and heart. New York, NY: Harcourt, Brace, Jovanovich.

Tian, Q., Liu, Y., \& Fan, J. (2015). The effects of external stakeholder pressure and ethical leadership on corporate social responsibility in China. Journal of Management \& Organization, 21(04), 388-410.

Treviño, L. K. (1986). Ethical decision making in organizations: A person-situation interactionist model. Academy of Management Review, 11(3), 601-617.

Treviño, L. K., \& Brown, M. E. (2004). Managing to be ethical: Debunking five business ethics myths. The Academy of Management Executive, 18(2), 69-81.

Treviño, L. K., Hartman, P. L. B., \& Hartman, M. (2000). Moral person and moral manager: How executives develop a reputation for ethical leadership. California Management Review, 42(4), $128-141$.

Tronto, J. C. (1993). Moral boundaries. New York: Routledge, Chapman, and Hall.

Trump, D. J., \& Schwartz, T. (1989). Trump: The art of the deal. New York: Warner Books.

Tucker, M. E. (2015). World religions, ethics, and the earth charter for a sustainable future. In R. Rozzi, F. S. Chapin, J. B. Callicott, S. T. A. Pickett, M. E. Power, J. J. Amesto, \& R. H. May (Eds.), Earth stewardship: Linking ecology and ethics in theory and practice (Vol. 2, pp. 395-405). Berlin: Springer.

Urien, B., \& Kilbourne, W. (2011). Generativity and self-enhancement values in eco-friendly behavioral intentions and environmentally responsible consumption behavior. Psychology and Marketing, 28(1), 69-90. 
Valente, M. (2012). Theorizing firm adoption of sustaincentrism. Organization Studies, 33(4), 563-591.

Van den Steen, E. (2005). Organisational beliefs and managerial vision. The Journal of Law, Economics, \& Organization, 21(1), 256-282.

Van der Byl, C. A., \& Slawinski, N. (2015). Embracing tensions in corporate sustainability: A review of research from win-wins and trade-offs to paradoxes and beyond. Organization \& Environment, 28(1), 54-79.

Viederman, S. (1994). The economics of sustainability: Challenges. In Paper presented at The Economics of Sustainability, Fundacao Joaquim Nabuco, Recife, Brazil.

Waldman, D. A., Siegel, D. S., \& Javidan, M. (2006). Components of CEO transformational leadership and corporate social responsibility. Journal of Management Studies, 43(8), 1703-1725.

Welch, J., \& Byrne, J. A. (2001). Jack: Straight from the gut. New York: Warner Books.

Whitehead, K. K. (2014). Sustainable development: Legitimisation to internalisation. International Journal of Sustainable Strategic Management, 4(3), 247-263.
Wink, P., \& Dillon, M. (2002). Spiritual development across the adult life course: Findings from a longitudinal study. Journal of Adult Development, 9(1), 79-94.

World Commission on Environment and Development. (1987). Our common future. Oxford: Oxford University Press.

Wright, C., \& Nyberg, D. (2016). An inconvenient truth: How organizations translate climate change into business as usual. Academy of Management Journal, 2015, 0718.

Wuthnow, R. (1998). After heaven: Spirituality in America since the 1950s. Berkeley, CA: University of California Press.

Zadek, S. (2004). The Path to corporate responsibility. Harvard Business Review, 82(12), 125-132.

Zelle, G. (2009). Exploring the application of positioning theory to the analysis of organisational change. In Paper presented at the Australian and New Zealand Academy of Management Conference, Adelaide, Australia. 